\title{
Symptomy relacji między społeczeństwem/narodem a państwem. Próba spojrzenia retrospektywnego w warunkach polskich
}

\begin{abstract}
Streszczenie: Problem relacji państwo a naród/społeczeństwo został podjęty z perspektywy przeszłości rzeczywistości polskiej. Autor starał się wskazać na wybrane przykłady tych uwarunkowań między „rządzącymi” a „rządzonymi”. Uwzględnia trzy wybrane zagadnienia - kryteria: 1) problem postaw - cech charakterologicznych Polaków, 2) problem mesjanizmu polskiego, 3) problem znaczenia koncyliaryzmu średniowiecznego. Stara się dowieść, że powyższe czynniki miały wpływ na ułożenie stosunków między państwem a narodem/społeczeństwem, oddziaływały na kształt podstaw ustrojowych demokracji szlacheckiej i zahamowały tendencje absolutystyczno-ustrojowe w systemie politycznym I Rzeczypospolitej. Skutki tych procesów odczuwamy w naszym kraju po dzień dzisiejszy.
\end{abstract}

Słowa kluczowe: państwo, naród, społeczeństwo, system polityczny

K iedy badamy współczesne systemy polityczne (gospodarcze) mamy do czynienia jednocześnie z państwem. Stawiane jest m.in. pytanie o udział danych grup społecznych w rządach itd. Jednak inaczej kształtowało się to w warunkach przeszłości niż współcześnie. Wynika to przede wszystkim z głębokiej ewolucji, jakiej podlegało państwo chociażby w samej epoce nowożytnej.

Mając na względzie podziały społeczne na „rządzących” i „rządzonych”, co nieraz było i jest rozpatrywane często bardziej intuicyjnie, aniżeli analitycznie, daje się zauważyć, iż u ich podstaw leżało przeciwieństwo dwóch niedających się rozdzielić czynników (elementów): społeczeństwa i państwa. Tzn. nie jest możliwe takie jednoznaczne, dychotomiczne ich rozdzielenie, co potwierdzają fakty społeczno-polityczne. W rzeczywistości społeczno-politycznej mamy dużo przykładów świadczących o uczestnictwie grup społecznych (ludzi) w sferze władzy, ale niebędących w pełni jej depozytariuszami (niemającymi pełni władzy).

Chciałbym zwrócić uwagę na ten fakt - zjawisko relacji państwo-społeczeństwo/naród, uwzględniając polską rzeczywistość (głównie tą z przeszłości) - na wybranych przykładach. Interesuje mnie problem uwarunkowań - przyczyn mających wpływ (znaczenie) na urządzenie stosunków między „rządzącymi” a „rządzonymi”. Uwzględniam trzy wybrane zagadnienia: 1) kwestię postaw - cech charakterologicznych Polaków; 2) problem mesjanizmu polskiego, 3) problem znaczenia koncyliaryzmu średniowiecznego.

Istotą państwa - m.in. - jest monopol legalnego używania przemocy (M. Weber nazywał to ,prawnym monopolem przymusu” - por. Z. Krasnodębski, 1999, s. 76 i n.). Rzecz w tym, że różne treści - historycznie kwestię ujmując - podkładano pod ową istotę. Trzeba pamiętać, że w dziejach Europy, w różnych systemach politycznych, dane formy władzy stanowiły pewien ciąg, z którego jednak trudno wyodrębnić jednoznacznie wyraźne typy państw. Ponadto tendencje integracyjne (do integrowania) nie wyznaczały w przeszłości europejskich stosunków międzynarodowych. W poprzednich wiekach międzynarodowy 
system władzy w Europie wyznaczały dwie sprzeczne tendencje: 1) tendencja do przyporządkowania słabszych państwom silniejszym; 2) tendencja do utrwalenia w państwach (monarchiach) wewnętrznych, regionalnych różnic administracyjno-ustrojowych, społeczno-kulturalnych itp. One kształtowały różnorodność polityczno-ustrojową Europy, układy sił społeczno-politycznych. Kiedy bierzemy pod uwagę nowoczesne państwo, to trudno - na pierwszy rzut oka - znaleźć pewną ciagłość i wspólne cechy np. z państwami stanowymi czasów późnego średniowiecza. Ale wystarczy odwołać się do idei kontroli władzy przez społeczeństwo (rozwijanej w zgromadzeniach stanowych), czy koncepcji przedabsolutystycznych, które znalazły się u podstaw nowożytnego parlamentaryzmu, ażeby takie powiązania znaleźć. Warto uwzględnić chociażby polską rzeczywistość społeczno-polityczną w przeszłości i współcześnie. Mamy tu na uwadze te dwa zasadnicze człony: społeczeństwo (naród) i państwo. Wydaje się, że na kształt relacji między nimi miały wpływ pewne cechy charakterologiczne Polaków, będące jakby symbiozą przesłania obiektywno-historycznego oraz przesłania subiektywnego (psychologicznego). Już Jan Długosz (1415-1480) wymieniał pewne cechy charakterologiczne Polaków: zawiść, obmowę, niechęć do „nauki, mądrości i cnoty” i ćwiczeń w sztuce wymowy. „Nic więc dziwnego - pisał - że czyny i zdarzenia u innych nacji były jak najbardziej opiewane i uświetniane przez talenty pisarskie, u Polaków zaś przeciwnie, rzeczy najwartościowsze i wspaniałe popadły w niepamięć i ciemność, a czyny i cnoty królów, książąt oraz bohaterstwa mężów i wodzów, koleje krajów i państw nie wydobyte na światło dzienne za pomocą pisma, skazane zostały na wieczną pomrokę i zepchnięte jak gdyby w wieczne ciemności przez niedbalstwo pisarzy; gdyby były zyskały ich łaskę, wsławione ich pochwałami błyszczałyby u potomnych, w nieśmiertelnej chwale" (J. Długosz, 2009, s. 69). Żyjący w tym samym XV wieku Grzegorz z Sanoka (1407-1477) podkreślał - z jednej strony - waleczność Polaków, ich wierność królowi, skromne ubiory, potępianie kradzieży, ale z drugiej - krytykował pijaństwo oraz rozprawianie nad kwestiami publicznymi w okolicznościach mało ku temu sprzyjającymi np. przy zabawach i ucztach. Dostrzegał też brak zainteresowania Polaków do osiedlania się w miastach. Nad skupiska miejskie Polacy przedkładali zamieszkiwanie w otwartych przestrzeniach, co miało potwierdzać ich indywidualizm i dążenie do wolności. „Jeśli zaś chodzi o nazwę - pisał Grzegorz z Sanoka - nie ulega wątpliwości, że jest ona nowa i tutejszego pochodzenia, mianowicie pochodzi od wyrazu, który my w naszym języku nazywamy pola. Ludzie bowiem, którzy wraz z ojczyzną opuścili mroczne lasy i dzikie góry, zachwyceni urokiem pól, które zamieszkali, nazwali się Polanami” (F. Kallimach Buonaccorsi, 1978, s. 525). Można zatem powiedzieć, że już od końca średniowiecza zwracano uwagę na umiłowanie wolności jako cechy wyróżniającej Polaków. Pomimo powszechnej akceptacji owej cechy, to jednak zdarzały się głosy krytyczne pod jej adresem. Wystarczy przywołać tutaj opinię Andrzeja Wolana (ok. 1530-1610), XVI-wiecznego teologa kalwińskiego, który pisał: „Jeśli jakikolwiek naród pysznił się z powodu swojej wolności, to nasz zaiste tak wielką sławę z tego powodu sobie przypisuje, że śmiało wysuwa się na czoło niemal wszystkich narodów. Nie tylko bowiem jednogłośnie na zjazdach i w licznych wypowiedziach wolność ta nasza jest sławiona, lecz również wiele pism poświadcza, jak wielkimi pochwałami ją się obsypuje i wielbi jako cechę szczególną i właściwą jedynie naszemu narodowi” (A. Wolan, 1978, s. 337). Teolog kalwiński sugerując daleko idącą wstrzemięźliwość w kwestii oceny własnego narodu (jego znaczenia), tłumaczył 
dalej, że realizacja wolności bez praw staje się niewykonalna, bo prowadzi do anarchii. Co więcej, ustosunkowując się do stanu praw w I Rzeczypospolitej, dowodził, że nie uwzględniają one wolności wszystkich stanów społecznych. W podobnym świetle o polskiej wolności wypowiadał się ks. Szymon Starowolski (1588-1656), pisarz polityczny i historyk (zob. Sz. Starowolski, 1979, s. 137-142). Mniej jednoznaczny zarówno w krytyce jak i pochwałach polskiej wolności był Łukasz Opaliński (1612-1662), marszałek nadworny koronny (zob. J. Domański, Z. Ogonowski, L. Szczucki, 1989, s. 429-432; por. J. Skoczyński, J. Woleński, 2010, s. 131-132). Najpełniejszy obraz charakterologiczny Polaków w XVII wieku przedstawił jezuita Maciej Kazimierz Sarbiewski (1595-1640). „Umysł mają chłonny na wszystko - pisał - co ich otacza, i w zdolnościach potrzebnych do zdobycia ogólnego wykształcenia nie ustępują nikomu. Umysłowość to jednak o ile podatna na wpływy, o tyle mało wytrwała, o ile posiadająca wielkie możliwości, o tyle nielubiąca wysiłków. Są jak pioruny, które jak uderzą, leżą tak jak każdy inny krzemień. Lepsi jesteśmy w pierwszym zapędzie, niż w stałym dążeniu. Wiele rzeczy w nas natura rozpoczyna, lecz niewiele tylko doprowadza do końca. Żaden naród łatwiej nie popada w gniew i łatwiej nie daje się uspokoić. Żaden nie podziwia goręcej cudzych obyczajów, zamiłowań, urządzeń, ale też mniej chętnie ich nie naśladuje. Wbrew naturalnemu porządkowi rzeczy, chwalimy to, czego nie robimy sami, ani nawet nie chcemy robić. Najczęściej bywa tak, że Polacy przeciętnie dobre rzeczy u innych podziwiają, ale własnymi nie gorszymi, albo i lepszymi gardzą. Chcieliby zawsze być czymś więcej, niż są, nigdy nie są z siebie zadowoleni. Ażeby coś im się wydało wielkim, musi być bardzo odległe. Nawet ojczyznę swoją kochają wtedy, gdy są z dala od niej, a będąc na miejscu nie cierpią jej, jakby po to wyjeżdżali za granicę, aby ją pokochać, a wracali, aby znienawidzić" (Sarbiewski, 1979, s. 126). Sarbiewski podkreślał zdolności intelektualne Polaków, ich zainteresowanie światem, przy jednoczesnym braku wytrwałości i cierpliwości. Wskazywał na swoisty determinizm geograficzny, tzn. uważał, że to warunki geograficzne miały wpływ na kształt zachowań i zalet charakterologicznych Polaków.

Już na przykładzie poglądów tych kilku pisarzy politycznych XV-XVII wieku można dostrzec, że akcentowano pozytywne cechy charakterologiczne Polaków (odwagę, poświęcenie, szczerość, zachwyt wolnością), a mniej było opinii krytycznych o nich (mniej było o wadach). Pisarze polityczni zaaferowani relacjami między „rządzącymi” a „rządzonymi” (między królem a szlachtą, magnateria) nie wypracowali ani projektu systemu w pełni absolutystycznego, ani projektu demokratyczno-przedstawicielskiego. Najczęściej jakby tkwili w pośrodku między tymi projektami. Wydaje się, że sytuacja w tej sprawie nie zmieniła się po dzień dzisiejszy: mamy rzeczników silnej władzy wykonawczej oraz zdeklarowanych zwolenników władzy ustawodawczej (przedstawicielskiej), no i całą rzeszę niezdecydowanych, pozostających między nimi. Wracając do przeszłości (Polski szlacheckiej), to w interesującym okresie wątek megalomanii narodowej nie był jeszcze przedmiotem szczególnego zainteresowania (poza franciszkaninem Wojciechem Dębołęckim/Dembołęckim; 1585-1646; perorującym o Królestwie Polskim jako najstarszym w Europie oraz o języku „słowieńskim” jako pierwotnym języku świata). Podobnie rzecz się miała ze sprawą mesjanizmu narodowego, aczkolwiek w tym wypadku mamy do czynienia z jego elementami (początkami) już od XV wieku. Trzeba pamiętać, że podstawą mesjanizmu jest wiara w zwycięstwo dobra nad złem. Wszystkie przeżycia mesjanistyczne biorą się z rozczarowania będącego rezultatem sy- 
tuacji ekonomiczno-społecznej oraz z rozczarowania ideologią (doktryną), religią, akceptowanymi do tej pory. W tych pragnieniach znajdujemy tęsknotę za wyidealizowaną rzeczywistością, za Bogiem prawdziwym i prawdziwym kościołem. Konkretyzacją owych pragnień pozostawała i pozostaje w dużej mierze wolna, niepodległa, obrastająca w dobra materialne ojczyzna. To przesłanie wyraża mesjanizm narodowy. Współtworzą go: 1) przeżycia religijne wraz z patriotycznymi; 2) świadomość o specjalnej misji dziejowej połączonej z pełnym wyzwoleniem - zbawieniem (mamy tutaj nawiązanie do mesjanizmu biblijnego); 3) oczekiwanie i prognozowanie klęski, wielkiej przemiany, na skutek których naród będzie zbliżał się do doskonałości. Uwzględniając te części składowe mesjanizmu narodowego do analizy polskiej rzeczywistości społeczno-politycznej, możemy powiedzieć, że tzw. mesjanizm polski odznacza się m.in.: 1) wyłączną akceptacją misji narodu polskiego jako szczególnej osobliwości moralnej; 2) akceptacją twierdzenia, że pierwotnym wzorem dziejów każdego narodu chrześcijańskiego są biblijne dzieje Izraela; na tej podstawie dzieje Polski są porównywalne do dziejów Izraela (w tym przekonaniu zawiera się element religijny); 3) argumentacją pozareligijną, czyli skomplikowanymi dziejami narodu polskiego. Jak patrzymy na dzieje mesjanizmu polskiego, to nie jest trudno zauważyć, że koncentrował się on na problematyce narodu - ojczyzny i jej podporządkował wszystko, co miało wpływ na jej dobro. W XIX wieku wyraźnie zostanie wyeksponowana idea niepodległości państwowej oraz idea jedności Polaków. Uwzględniając czas dzisiejszy (współczesny) i zjawisko podejmowania prób odrodzenia mesjanizmu polskiego nie zauważamy odwoływania się do tej ostatniej idei (chyba że niekiedy tylko w sferze postulatywnej, ale nie w sferze realizacji).

Początki mesjanizmu polskiego sięgają czasów XV wieku. Już Stanisław ze Skarbimierza (zm. w 1431 r.), pierwszy rektor odnowionego Uniwersytetu Krakowskiego, w swoim kazaniu pt. Pochwała Uniwersytetu na nowo ufundowanego wyraził opinię, że Polska jest krajem najbardziej uprzywilejowanym i wybranym. W XVI wieku ks. Stanisław Orzechowski (1513-1566), pisarz polityczny i religijny, będzie udowadniał, że królestwo polskie było od czasów Bolesława Chrobrego aż do końca panowania Zygmunta Starego państwem wolności, sprawiedliwości i prawdziwej wiary, narodem wybranym i umiłowanym przez Boga, którego porządek ustrojowo-prawny stał wyżej niż w Cesarstwie Niemieckim. Najpełniejszy wyraz mesjanizm polski uzyskał w poglądach jezuity, ks. Piotra Powęskiego - Skargi (1536-1612), autora słynnych Kazań sejmowych. Nazywany „prorokiem narodu polskiego" Skarga zaprezentował wizję polityczno-profetyczną Rzeczypospolitej, opartą na dużym poczuciu dumy narodowej i uwypukleniu wielkiego znaczenia narodu dla tamtej rzeczywistości społeczno-politycznej. W tej charakterystyce nawiązywał do porównań z narodem izraelskim (na płaszczyźnie historyczno-religijnej, społecznej, spirytualistyczno-mesjańskiej). W ten sposób rodził się obraz Polski jako ziemi świętej, przedmurza chrześcijaństwa w Europie - jako wyrazu sensu istnienia historycznego oraz wyjątkowej opieki bożej, państwa, którego istotę wyznaczały hasła wolności, pacyfizmu (stosunek do wojen zaborczych) i dobrych obyczajów (gościnność). Podstawowym obowiązkiem miała być miłość ojczyzny jako wspólnoty, rodziny i matki. Mając na uwadze istniejące zło społeczno-moralne, znajdujące odzwierciedlenie w takich wadach, jak: kłótliwość, chęć kradzieży, żądza urzędów i sławy, pycha, Skarga utożsamiał się z prorokami Izraela na płaszczyźnie posłannictwa. Rzeczypospolita pozostawała przedmiotem troski Boga jako Królestwa Chrystusa i z tego powodu 
- zdaniem Skargi - Bóg wysyła do niej swoich proroków będących ostatnią szansą dla narodu, dla jego egzystencjalnego bytu. Oczywistością jakby pozostawało trwanie Polski przy Kościele. To takie profetyczne przesłanie, płynące z koncepcji Skargi, akcentowanie sensu cierpienia uprzedmiotowionego w narodzie miały znaczenie aksjologiczne najwyższe. Bowiem status narodu wyznaczało zadanie, jakie przed nim stało. W ten sposób naród polski jako „mesjasz” wśród innych narodów i cierpiący za nie, wyznaczał kształt i poziom świadomości patriotycznej.

Ten polski mesjanizm przełomu XVI i XVII wieku to swoiste preludium do mesjanizmu XIX-wiecznego. Wydaje się, że świadomość mesjanistyczna przyczyniła się do przetrwania naszego narodu w warunkach bezpaństwowych w XIX wieku. Odwołując się do transcendencji wobec rzeczywistości, świadomość mesjanistyczna w polskim wydaniu (w przeszłości) przyczyniła się do utrwalenia znaczenia czynnego uczestnictwa narodu (społeczeństwa) w procesie historycznym, wskazała na rolę aktywnego działania (specjalnej misji) w procesie przemian społecznych. W ogóle, jak patrzymy na dzieje nasze, na naszą kulturę, to Polacy wyżej cenili działanie - chociażby w deklaracjach i na płaszczyźnie programowej. Już Jan z Ludziska (ok. 1400 - przed 1460), rektor Uniwersytetu Krakowskiego, wprowadził podział na życie kontemplatywne i aktywne. To pierwsze - nie było naturalną formą ludzkiego bycia. Natomiast życie aktywne (działanie) było sposobem istnienia człowieka, które otrzymał od natury. To ono zadecydowało o charakterze kultury polskiej (dość jednostronnej w swoim wymiarze), zdominowanej przez umysłowość praktyczną, która w relacjach między „rządzącymi” a „rządzonymi” przybierała często formę poczucia obywatelskiej cnoty i obowiązku. W związku z tym bardzo trafna była opinia Mariana Massoniusa na początku XX wieku, który nawiązując do sfery praktyki i sfery teorii, dowodził, że „Polak, nie mający przyrodzonej namiętności do rozwiązywania zagadnień teoretycznych, o ile się swego swoistego pojęcia 'cności' nie wyzbywa albo o ile się wprost 'bezcennym' nie staje, musi widzieć wartość obywatelską i użyteczność społeczną tego, co czyni. Więc godzi się na działalność naukową, więc ją nawet pochwala i popiera, gdy z jej wyników obiecuje sobie wzrost dobra społecznego, słowem gdy ją nie jak naukę, ale jak oświatę traktuje" (Massonius, 1980, s. 488). Wracając do kwestii mesjanizmu polskiego (świadomości mesjańskiej), to nasuwa się pytanie samo przez się: czy można snuć paralele między - że tak powiem - klasycznym mesjanizmem polskim a odradzającymi się ideami neomesjańskimi w dzisiejszych czasach? Oczywiście można, ale należy pamiętać o zupełnie odmiennych uwarunkowaniach historyczno-kulturowych, polityczno-społecznych, ekonomicznych itd. Ponadto życie narodu nie sprowadza się tylko do tradycji - którą współkształtują takie czynniki jak: wiedza, moralność i dzieje - postrzeganej jako zasada życia. Tak uważało i uważa wielu Polaków. Jestem skłonny twierdzić, że zasadą życia jest teraźniejszość (warunki i potrzeby społeczne), zaś przeszłość stanowi jedynie podstawę.

Wreszcie problem trzeci - zjawisko koncyliaryzmu w Kościele, które miało swoje przełożenie na etykę społeczną XV wieku, w państwie Jagiellonów. Ta etyka wyrastała z demokratyzmu, który przeciwstawiał się teokratyzmowi i absolutyzmowi. A propos koncyliaryzmu, trzeba pamiętać, że był on zjawiskiem złożonym, swoistą koncepcją władzy i na dodatek rozłożoną w czasie (nie dotyczył tylko XIV i XV wieku). Poprzez odwoływanie się do znaczenia prawa naturalnego, zwolennicy koncyliaryzmu formułowali (co prawda w sposób szkicowy) zalążki koncepcji rozdziału Kościoła od pań- 
stwa. Wystarczy przywołać tutaj poglądy Pawła Włodkowica z Brudzenia (ok. 1370-ok. 1435), który za swoim mistrzem Francesco Zabarellą z Padwy (1360-1417) dał pierwszy symboliczny szkic - koncepcję pewnego ładu społecznego (życia zbiorowego), który później określił jako autonomię porządku doczesnego. Koncyliaryzm miał wpływ na rozwój koncepcji społecznych, na proces kształtowania się moralności politycznej w późnym Średniowieczu. Dawało to się zauważyć w czterech płaszczyznach problemowych: a) pojmowaniu społeczeństwa jako wspólnoty; b) podkreślaniu znaczenia i roli prawa i praworządności w życiu społeczno-politycznym; c) akcentowaniu zasad tolerancji oraz zasad pluralizmu; d) zaznaczaniu znaczenia tendencji irenicznych i uniwersalistycznych w procesie kształtowania struktur polityczno-państwowych, organizacyjnych społeczeństwa. Nie rozwijając tych problemów, chcemy tutaj tylko podkreślić, że z pojęciem wspólnoty były związane inne, istotne dla rozwoju demokracji, systemu parlamentarno-konstytucjonalnego pojęcia: ludu, ugody społecznej (zasady consensusu), przedstawicielstwa (zasady repraesentatio). Potwierdzenie tego znajdujemy już u Wincentego Kadłubka (ok. 1160-1223), który w swojej Kronice polskiej dowodził, że władza królewska pochodzi od ludu. Podobny sąd o wszelkiej władzy później głosił wspomniany już Paweł Włodkowic. Co do terminu repraesentatio, to on jakby dokumentował (uzasadniał) konieczność wyboru przedstawicieli całej wspólnoty dla zabezpieczenia interesów wszystkich jej członków. To było praźródło późniejszej zasady każdej demokracji: nic o nas bez nas". Bardzo ważną kwestią dla ułożenia stosunków między społeczeństwem a państwem miała zasada wyższości prawa nad panującym (władca, monarchą). Chodziło przede wszystkim o prawo naturalne i stopniowo nabierające na znaczeniu prawo zwyczajowe. Stosowanie w praktyce reguł prawa naturalnego wymuszało nie tylko rozwiniętej coraz bardziej cnoty sprawiedliwości u ogółu obywateli, ale też specjalnej cnoty nazywanej epikeiq, rozumianej jako sprawność słusznego konkretyzowania sprawiedliwości w danych, rzeczywistych warunkach. W XV wieku myśliciele krakowscy (Mateusz z Krakowa, Stanisław ze Skarbimierza, Paweł Włodkowic) w oparciu o zasady prawa naturalnego, tworzyli teorię życia zbiorowego oraz prawa wojny. Stanisław ze Skarbimierza (ok. 1360-1431) będzie pisał: ,,[...] przede wszystkim władcy i dostojnicy powinni dążyć do tego [...], by ojczyzna, królestwo czy prowincja rządzone były z przestrzeganiem prawa sprawiedliwego, rozumnego i szlachetnego. Powiem raz jeszcze: prawa sprawiedliwego i rozumnego, bo istota prawa opiera się na rozumie. Dlatego, jeśli prawo jest sprzeczne z rozumem albo jeśli jest niesprawiedliwe, nieszlachetne, szkodliwe albo, co gorsza, prowadzące do duchowej zatraty, nie zasługuje na miano prawa, bo jest prawem niegodziwym [...]. Któż bowiem przy zdrowych zmysłach dopuścił do tego, aby prawo stało się więzami niegodziwości? Dlatego jeśli jakieś przepisy prawne prowadzą do grzechu ciężkiego albo stanowią przeciw dobrym obyczajom, albo sprzeciwiają się prawu Chrystusowemu, albo jeśli służą oszczerstwu, muszą być natychmiast wycofane" (Stanisław ze Skarbimierza, 2000, s. 51). Obok podkreślania znaczenia prawa w życiu społeczno-politycznym, podnoszono fakt - zasadę pluralizmu, przybierający generalnie oblicze dwojakie (w zależności od rozłożonych w nim akcentów moralnych). A więc pluralizm może być pluralizmem egocentrycznym, sprzyjającym hasłom szowinizmu i absolutyzmu. Albo może przyczynić się do kreowania postaw otwartości i tolerancyjności, tym samym wychodzić naprzeciw budowaniu struktur federacyjnounijnych. Pod koniec Średniowiecza dała o sobie znać ta druga wersja pluralizmu, czego 
wyrazem były różne tendencje ireniczne, znajdujące potwierdzenie w poszukiwaniach pokoju, w dążeniach do budowania swoistych ,terenów zgody” tak w teorii, jak i praktyce, w dążeniach do bliższych kontaktów z wszystkimi, którzy byli ,inni” (nie chodziło o totalną krytykę i potępienie, ale o możliwość zrozumienia i poznania owej inności). Ten ireniczny pluralizm leżał u podstaw podejmowanych wysiłków w praktyce politycznej na rzecz polityki pokojowej, antywojennej. Przykładem tego w dziejach Polski była realizacja pokojowej polityki za panowania Zygmunta Starego. Warto przy tej okazji wspomnieć słynne kazanie Stanisława ze Skarbimierza De bello iusto et iniusto (w zasadzie pierwszy traktat o prawie wojny), który na koniec tak mówił/pisał: „Tak wszyscy niech pokój miłują, że nawet, jeśli zachodzi potrzeba, aby był pokój na ziemi, niech się na śmierć narażają, aby tak służąc Panu Bogu, jak powinni, w pokoju doczesnym, mogli szczęśliwie dojść do pokoju wiekuistego, dokąd nie przybliża się żaden prześladowca, który by mógł go zamącić” (Stanisław ze Skarbimierza, 2000, s. 111). Wiemy, że pomimo tych faktów, wersja pluralizmu otwartego na postawy ireniczne i tolerancyjne przegrała i zwyciężył pluralizm egocentryczny wspomagający systemy absolutne. Tym niemniej został przygotowany grunt ideowy pod przyszłe poczynania następnych pokoleń w kwestii budowania społeczeństwa obywatelskiego.

Reasumując, kształtowanie się cech charakterologicznych Polaków, poczynając od późnego Średniowiecza, w połączeniu z dziejącymi się obiektywnymi procesami historycznymi, specyficzność zjawiska mesjanizmu polskiego, znaczenie koncyliaryzmu dla demokratyzmu polskiego - wskazałem tutaj tylko na te trzy czynniki - odbiły się na ułożeniu stosunków między państwem a narodem (społeczeństwem) - formowaniu się podstaw ustrojowych demokracji szlacheckiej i tym samym stanęły naprzeciw tendencjom absolutystyczno-ustrojowym w systemie politycznym dawnej Rzeczypospolitej. Skutki owych długotrwałych procesów ustrojowo-polityczno - kulturowych odczuwamy w naszym kraju po dzień dzisiejszy.

\section{Bibliografia}

Długosz J. (2009), List dedykacyjny, w: tegoż, Roczniki, czyli kroniki sławnego Królestwa Polskiego, red. Ir. Tatarczukowa, Wydawnictwo Naukowe PWN SA, Warszawa, ks. I, s. 63-79.

Domański J., Ogonowski Z., Szczucki L. (1989), Zarys dziejów filozofii w Polsce. Wieki XIII-XVII, PWN, Warszawa.

Kallimach Buonaccorsi F. (1978), Życie i obyczaje Grzegorza z Sanoka, w: Filozofia i myśl spoleczna XIII-XV wieku, red. J. Domański, PWN, Warszawa, s. 523-534.

Krasnodębski Z. (1999), M. Weber, Wiedza Powszechna, Warszawa.

Massonius M. (1980), Rozdwojenie myśli polskiej (R. XI „, Pozytywizm krytyczny”), w: Filozofia i myśl spoteczna w latach 1865-1895, cz. 2, red. A. Hochfeldowa, B. Skarga, PWN, Warszawa, s. $488-501$.

Sarbiewski M. K. (1979), Charakterystyka Polaków, w: Filozofia i myśl społeczna XVII wieku, cz. 1, red. Z. Ogonowski, PWN, Warszawa, s. 126-128.

Skoczyński J., Woleński J. (2010), Historia filozofii polskiej, WAM, Kraków.

Stanisław ze Skarbimierza (2000), Mowy wybrane o mqdrości, oprac. Mir. Korolko, Wydawnictwo Arcana, Kraków.

Starowolski Sz. (1979), O wolności bez swawoli, w: Filozofia i myśl społeczna XVII wieku, cz. 1, red. Z. Ogonowski, PWN, Warszawa, s. 137-142. 
Wolan A. (1978), O wolności politycznej, czyli obywatelskiej, w: Filozofia i myśl społeczna XVI wieku, red. L. Szczucki, PWN, Warszawa, s. 333-356.

\title{
Expressions of relations between the society/nation and the state. A retrospective approach in the Polish context
}

\begin{abstract}
Summary
The relations between the state and the nation/society are approached in the context of Polish history. The author examines selected examples of the interactions between those in power and the governed populace by focusing on: 1) attitudes - the character features of the Poles; 2) the Polish historical mission; 3 ) the influence of Medieval conciliatory attitudes. The work attempts to prove that these factors influenced the relations between the state and the people, formed the foundations of nobles' democracy and inhibited absolutism tendencies in the political system of the First Republic. The effects of those processes are also visible in today's Poland.
\end{abstract}

Key words: state, nation, society, political system 